\title{
Prognostic significance of ST-T segment alterations in patients with non-Q wave myocardial infarction
}

José Antônio F Ramires, Carlos V Serrano, Maria C Solimene, Paulo J Moffa, Bruno Caramelli, Fúlvio Pileggi

\begin{abstract}
Objective-To determine whether, among patients with non-Q wave myocardial infarction, the characteristics of the segment ST-T shifts at presentation in the diagnostic electrocardiogram can identify those with more severe coronary artery disease and predict a poor clinical outcome.

Design-Prospective controlled clinical trial.

Setting-Primary referral medical centre. Patients-93 patients (mean (SD) 62.0 $(7 \cdot 5)$ years) were studied: 41 with non- $Q$ wave myocardial infarction and $T$ wave inversion and 52 with ST segment depression. Cardiac events and mortality rates were assessed over 42 months. Age, sex, risk factors, creatine kinase $\mathrm{MB}$ isoenzyme peak, and left ventricular function were comparable.
\end{abstract}

Results-31 patients with $T$ wave inversion myocardial infarction $(94.6 \%)$ had total occlusion of the infarct related artery, compared with 12 patients with ST segment depression myocardial infarction $(26.7 \%)(P<0.05)$. When compared with patients with $T$ wave inversion, patients with ST segment depression had a higher incidence of cardiac events during the first month and in the 41 subsequent months: $9.6 \%$ and $30.8 \% v 0 \%(P<0.01)$ and $9.8 \%$ $(P<0.02)$, respectively. For the same observation periods, the mortality rates in patients with $T$ wave inversion were $4.9 \%$ and $7 \cdot 3 \%$, and in patients with ST segment depression they were $5 \cdot 8 \%$ and $9.6 \%$, respectively.

Conclusion-These data suggest that during a non- $Q$ wave myocardial infarction the presence of ST segment depression is related to higher rates of short and long term cardiac events when compared with $T$ wave inversion-possibly because of a higher incidence of residual stenosis of the infarct related artery.

(Heart 1996;75:582-587)

Keywords: acute myocardial infarction; non-Q wave myocardial infarction; reinfarction; prognosis

Prognosis after an acute myocardial infarction depends largely on infarct size, left ventricular function, residual myocardium in jeopardy, state of coronary circulation, and the presence of complex ventricular arrhythmias at hospital discharge. ${ }^{1-6}$ Recently, several studies have emphasised important clinical differences between patients with non- $Q$ wave and $Q$ wave myocardial infarction that may have prognostic and therapeutic implications. It is known that patients with non-Q wave infarction have smaller infarct size and greater residual myocardium at risk than patients with $Q$ wave infarction..$^{78}$ These findings are based on studies that have shown that subtotal occlusion of the infarct related artery is more frequent among patients with non- $Q$ wave myocardial infarction..$^{9}{ }^{10}$ This angiographic picture probably explains the higher incidence of recurrent ischaemic events in patients with non- $Q$ wave infarction than in those with $Q$ wave infarction. $^{9-12}$

However, little is known about the prognostic significance of early ST-T segment shifts present in patients during the evolution of a non-Q wave myocardial infarct. Since most myocardial infarcts (within the first several hours) begin without $Q$ waves, it is important to establish whether the early electrocardiographic (ECG) findings differ appreciably from those normally encountered in Q wave myocardial infarction and whether ST-T segment shifts provide any meaningful information about short and long term outcomes.

The objective of our study was therefore to determine whether, among patients with non- $Q$ wave myocardial infarction, ST-T segment shifts would identify those with a more severe coronary artery disease and predict a poor clinical outcome.

\section{Methods}

This study was part of a population based investigation of temporal trends in the incidence and case fatality rates of patients admitted to hospital with acute myocardial infarction in the Heart Institute (São Paulo, Brazil). All patients were admitted with predefined diagnostic criteria for acute myocardial infarction.

\section{STUDY POPULATION}

From a total of 1287 patients with acute myocardial infarction admitted in our hospital, 93 (82 men; mean (SD) age $62.0(7 \cdot 5)$ ) presented with a non-Q wave myocardial infarction and were studied prospectively for 42 months. Patients with any of the following conditions were excluded from the study: refused to participate; more than $24 \mathrm{~h}$ from onset of symptoms; use of thrombolytics; past history of myocardial infarction or congestive heart failure; left ventricular hypertrophy. Patients were 
Table 1 Medical treatment, distribution of baseline characteristics, and angiographic aspects of the patients with non- $Q$ wave myocardial infarction. Values are mean (\%) or mean (SD)

\begin{tabular}{|c|c|c|}
\hline & $\begin{array}{l}T \text { wave inversion } \\
(n=41)\end{array}$ & $\begin{array}{l}S T \text { segment depression } \\
(n=52)\end{array}$ \\
\hline $\begin{array}{l}\text { Medical treatment } \\
\text { Intravenous glyceryl trinitrate } \\
\text { Oral nitrates } \\
\beta \text { blockers } \\
\text { Calcium channel blockers } \\
\text { Aspirin } \\
\text { Lignocaine }\end{array}$ & $\begin{array}{l}30(73 \cdot 2 \%) \\
40(97 \cdot 6 \%) \\
31(75 \cdot 6 \%) \\
33(80 \cdot 5 \%) \\
40(97 \cdot 6 \%)^{\star} \\
5(12 \cdot 2 \%)\end{array}$ & $\begin{array}{l}47(90 \cdot 4 \%) \\
50(96 \cdot 2 \%) \\
39(75 \cdot 0 \%) \\
42(80 \cdot 8 \%) \\
52(100 \%) \\
11(21 \cdot 2 \%)\end{array}$ \\
\hline $\begin{array}{l}\text { Distribution of baseline characteristics } \\
\text { Age (years) } \\
\text { Male } \\
\text { Risk factors }\end{array}$ & $\begin{array}{l}63(5) \\
38(93 \%)\end{array}$ & $\begin{array}{l}61(8) \\
44(84 \cdot 6 \%)\end{array}$ \\
\hline $\begin{array}{l}\text { Dislipidaemia } \\
\text { Smoker } \\
\text { Diabetes mellitus } \\
\text { Arterial hypertension } \\
\text { Pain duration (h) } \\
\text { CKMB peak (IU/litre) }\end{array}$ & $\begin{array}{l}14(34 \cdot 1 \%) \\
11(26 \cdot 8 \%) \\
5(12 \cdot 2 \%) \\
17(41 \cdot 5 \%) \\
7 \cdot 2(5 \cdot 1) \\
55(8)\end{array}$ & $\begin{array}{l}14(26 \cdot 9 \%) \\
11(21 \cdot 2 \%) \\
5(9 \cdot 6 \%) \\
17(32 \cdot 7 \%) \\
8 \cdot 4(6 \cdot 5) \\
49(10)\end{array}$ \\
\hline $\begin{array}{l}\text { Site of qualifying infarct } \\
\text { Anterior wall } \\
\text { Inferior wall } \\
\text { Lateral wall }\end{array}$ & $\begin{array}{r}23(56 \cdot 1 \%) \\
6(14 \cdot 6 \%) \\
12(29 \cdot 3 \%)\end{array}$ & $\begin{array}{r}31(59 \cdot 6 \%) \\
6(11 \cdot 6 \%) \\
15(28 \cdot 8 \%)\end{array}$ \\
\hline $\begin{array}{l}\text { Angiographic aspects } \\
\text { Cineangiograms performed } \\
\text { Infarct related artery }\end{array}$ & $37(90 \%)$ & $45(87 \%)$ \\
\hline $\begin{array}{l}\text { Right coronary } \\
\text { Left anterior descending } \star \star \\
\text { Left circumflex } \\
\text { Occlusion of infarcted related artery } \\
\text { Number of coronary arteries with lesion } \neq\end{array}$ & $\begin{array}{c}5(13 \cdot 5 \%) \\
25(67 \cdot 6 \%) \\
7(18 \cdot 9 \%) \\
35(94 \cdot 6 \%) \dagger\end{array}$ & $\begin{array}{c}4(8 \cdot 9 \%) \\
35(77 \cdot 8 \%) \\
6(13 \cdot 3 \%) \\
12(26 \cdot 7 \%) \dagger\end{array}$ \\
\hline $\begin{array}{l}\text { One } \\
\text { Two } \\
\text { Three } \\
\text { Left ventricular ejection fraction }\end{array}$ & $\begin{array}{c}16(43 \cdot 2 \%) \\
10(27 \cdot 0 \%) \\
11(29 \cdot 7 \%) \\
0 \cdot 65(0 \cdot 12)\end{array}$ & $\begin{array}{c}13(28 \cdot 9 \%) \\
19(42 \cdot 2 \%) \\
13(28 \cdot 9 \%) \\
0.58(0 \cdot 09)\end{array}$ \\
\hline
\end{tabular}

CKMB, creatine kinase MB isoenzyme.

*One patient had aspirin stopped because of peptic ulcer.

$\star \star$ One patient had aspirin sto
$\star$ Intergroup: $P<0.05$.

$\ddagger \geqslant 70 \%$ obstruction. be transient if, on resolution of the pain, the $T$ waves and ST segments returned to the level and configuration obtaining before the pain occurred. (3) Cardiac enzymes: elevation of serum creatine kinase-MB (CKMB) levels above $20 \mathrm{IU} /$ litre sampled every $6 \mathrm{~h}$ within $48 \mathrm{~h}$ after the onset of precordial pain.

\section{CARDIAC CATHETERISATION TECHNIQUE}

Two to 12 days following the myocardial infarct, coronary arteriography and left ventriculograms were performed by the ShireySones technique. The angiograms were reviewed for the presence of significant coronary artery narrowing, defined as a diameter reduction of $\geqslant 70 \%$. The coronary artery lesions were further evaluated for the location of the narrowing or obstruction in each vessel, and the presence and origin of collateral blood flow. Global left ventricular ejection fractions were calculated using an area-length technique. $^{13}$

\section{CLINICAL PROTOCOL}

The subjects were admitted to coronary care units and treated with analgesia (morphine), adequate oxygenation, bed rest, anxiety reduction (diazepam $5 \mathrm{mg}$ orally four times a day), and correction of disturbances of acid-base balance and electrolytes.

During the early phase of myocardial infarction, patients with evolving congestive heart failure underwent specific haemodynamic and pharmacological management, including inotropic support. Other complications such as ventricular tachyarrhythmias were treated similarly.

wave equivalent posterior myocardial infarction. Fifty four patients with non- $Q$ wave myocardial infarction were excluded from the study since they arrived at the hospital with symptoms for more than $24 \mathrm{~h}$ (range 1.3$8 \cdot 6 \mathrm{~d})$.

The patients were divided according to ST$\mathrm{T}$ segment alterations in their diagnostic ECG: there were 41 patients $(44 \cdot 1 \%)$ with $T$ wave inversion and 52 patients $(55.9 \%)$ with ST segment depression.

\section{DIAGNOSIS OF NON-Q WAVE ACUTE} MYOCARDIAL INFARCTION

Criteria for inclusion of patients in the study were based on the diagnosis of non-Q wave acute myocardial infarction, which needed the presence of two of the following: (1) Chest pain: history of precordial pain was defined as the presence of typical cardiac chest pain lasting more than $20 \mathrm{~min}$. (2) ECG coding: 12-lead resting ECG on admission showing sustained $T$ wave inversion or ST segment depression $(\geqslant 2$ $\mathrm{mm}$ ), and absence of $Q$ waves $\geqslant 1 \mathrm{~mm}$ in depth and $\geqslant 0.02 \mathrm{~s}$ in duration. The ECG was obtained every $3 \mathrm{~h}$ during the first 24-48 h of myocardial infarction. Patients who initially had ST segment depression on their admission ECG and later evolved to combined $T$ wave inversion were considered to be in the ST segment depression group. The diagnostic ECGs of all study patients were reviewed by two investigators to reach agreement on the magnitude of $T$ wave inversion and ST segment depression. ST-T changes were considered to

\section{CLINICAL AND LABORATORY EVALUATION}

After admission the following evaluations were performed: (1) daily clinical examination by the investigator; (2) 12-lead ECG, daily for the first $4 \mathrm{~d}$, then on alternate days until $10 \mathrm{~d}$ or hospital discharge; (3) ECG at the time of recurrent pain and for a minimum of three consecutive days if reinfarction was suspected; and (4) serial blood samples for analysis of CKMB activity. Sampling times consisted of an initial sample at the time of admission, followed by samples drawn every $6 \mathrm{~h}$ thereafter throughout $2 \mathrm{~d}$. Additional samples were collected at least every $8 \mathrm{~h}$ for the subsequent $72 \mathrm{~h}$ in patients in whom reinfarction was suspected. The subsequent clinical course was evaluated weekly in the rest of the first month, monthly during the following three months, quarterly during the first year, and then intermittently until the 42nd month after the infarction.

\section{TREATMENT REGIMEN}

As seen in table 1 , all patients received standard medical treatment in accordance with conventional guidelines, and there were no significant differences among the two groups of patients. Use of glyceryl trinitrate, $\beta$ blocking drugs, calcium channel blocking agents, salicylates, and low dose heparin was permitted when indicated. Initial treatment for angina included sublingual glyceryl trinitrate or morphine. The approach to angina refractory to medical treat- 
ment (long acting nitrates, intravenous glyceryl trinitrate, $\beta$ blocking drugs, and calcium channel blocking agents) was individualised and patients had coronary angioplasty or surgery if necessary.

\section{DEFINITION OF ENDPOINTS}

The primary endpoint of the study was a cardiac event within two periods: in the first month after the infarction, defined as short term follow up, and in the 41 subsequent months, defined as long term follow up. A "cardiac event" was defined as follows: (1) unstable angina, defined as a new occurrence of typical ischaemic chest pain that developed at rest or with minimal effort, and was associated with transient ECG alterations and without a new rise in plasma CKMB activity; (2) reinfarction, defined as the presence of at least two of the following: (a) recurrent and persistent ischaemic pain while in hospital more than $24 \mathrm{~h}$ after admission, (b) increase in CKMB level of at least $20 \%$ over the last abnormal value, and (c) new persistent ECG changes; (3) congestive heart failure, New York Heart Association classification class II to IV during the late evolution period, and Killip-Kimbal class II to IV classification during in-hospital evaluation; (4) percutaneous transluminal coronary angioplasty or coronary artery bypass graft surgery-treatments indicated at any time during the study because of critical stenosis ( $\geqslant 95 \%$ ).

The other endpoint of the study was death secondary to cardiac causes, also within the same observation periods.

\section{STATISTICAL ANALYSIS}

Means (SD) (range) were calculated for continuous variables, and absolute and relative frequencies were measured for discrete variables. Comparisons between groups were carried out by Student's $t$ test in the case of continuous variables and by the $\chi^{2}$ test. The independent effect of selected clinical variables on short term mortality was assessed and estimated as relative risks with corresponding $95 \%$ confidence intervals. The following variables were included in this multivariate analysis: age, sex, coronary risk factors (hypercholesterolaemia, smoking, diabetes mellitus, and systemic arterial hypertension), duration of chest pain, site of qualifying infarct (anterior, inferior, or lateral wall), and serum CKMB findings. For long term analysis, survival rates were calculated by the HaenszelMantel method. All tests were two tailed, and a $P$ value of $\leqslant 0.05$ was considered to indicate statistical significance.

\section{Results}

CONTRIBUTION OF BASELINE CHARACTERISTICS Patients with both $T$ wave inversion and ST segment depression non- $Q$ wave myocardial infarction had a similar distribution of baseline characteristics relating to age, sex, pain duration, maximum CKMB values, coronary risk factors, site of qualifying infarct (table 1), and concurrent treatment with $\beta$ blocking drugs, nitrates, calcium channel antagonists, and antiplatelet agents.

\section{ANGIOGRAPHIC DATA}

Coronary arteriography and left ventriculograms were performed in 37 of the patients $(90.2 \%)$ with $\mathrm{T}$ wave inversion, and in 45 of the patients $(86.5 \%)$ with ST segment depression. We found no angiographic differences between these two sets of patients concerning the infarct related coronary artery, the number of coronary arteries with disease $(\geqslant 70 \%$ obstruction), and left ventricular ejection fraction. The left anterior descending coronary artery was the vessel most affected by obstructive disease in the study $(67 \cdot 6 \%)$, independently of ST-T alterations (table 1).

Only $26 \cdot 7 \%$ of the patients with ST segment depression had total occlusion of the infarct related artery in their coronary arteriograms, while $94.6 \%$ of the $\mathrm{T}$ wave inversion patients had total occlusion $(P<0.05)$.

\section{IN-HOSPITAL CLINICAL COURSE}

Independent of the type of non- $Q$ myocardial infarction ( $T$ wave inversion or ST segment depression), more than $95 \%$ of the patients studied showed no or mild clinical manifestations of left ventricular failure during their inhospital clinical course as they evolved in Killip classes I-II (table 2).

In addition, two patients (4\%) with ST segment infarction developed ventricular tachyarrhythmias, while none of the patients with $\mathrm{T}$ wave inversion myocardial infarction had such arrhythmias in the postinfarction period (table 2).

\section{CARDIAC EVENTS}

During the 42 month follow up period, 26 $(27.9 \%)$ of the original 93 patients had a cardiac event. Compared with patients with $\mathrm{T}$ wave inversion, patients with ST segment depression showed a higher incidence of cardiac events during the first month and during the 41 subsequent months postinfarction: $9 \cdot 6 \%$ and $30.8 \%$ v $0 \%(\mathrm{P}<0.01)$ and $9.8 \%(\mathrm{P}<$ 0.02 ), respectively (table 3 ).

Overall, the cardiac event encountered most frequently was the need for coronary angioplasty or a surgical bypass treatment $(52 \cdot 0 \%)$. These procedures were indicated because angiography showed critical stenosis in the infarct related artery or in other coronary arteries. The cardiac catheterisations were performed between two and 12 days postinfarction. Another interesting observation is that none of the patients with $T$ wave inversion in their diagnostic ECG had a cardiac event during the first postinfarction month and only four had an event during the 41 subse-

Table 2 Incidence of congestive heart failure (CHF) and ventricular arrhythmia according to the type of non- $Q$ wave myocardial infarction during the 42 month study period. Data are expressed as number of patients or as incidence (\%) to related variable

\begin{tabular}{lll}
\hline CHF (Killip class) & $\begin{array}{l}T \text { wave inversion } \\
(n=41)\end{array}$ & $\begin{array}{l}S T \text { segment depression } \\
(n=52)\end{array}$ \\
\hline I-II & $40(98 \%)^{\star}$ & $50(96 \%) \dagger$ \\
III-IV & $1(2 \%)^{\star}$ & $2(4 \% \dagger$ \\
VT/VF & $0(0 \%)$ & $2(4 \%)$ \\
\hline
\end{tabular}

VT/VF, ventricular tachycardia/ventricular fibrillation $\star$, +Intragroup: $P \leqslant 0.05$. 
Table 3 Incidence of cardiac events (deaths excluded) according to the type of non- $Q$ wave myocardial infarction during the first month and 41 subsequent months after myocardial infarction. Data are expressed as number of patients or as incidence (\%) to related variable

\begin{tabular}{llllll}
\hline & $\begin{array}{l}T \text { wave inversion } \\
(n=41)\end{array}$ & & \multicolumn{2}{l}{$\begin{array}{l}S T \text { segment depression } \\
(n=52)\end{array}$} \\
\cline { 2 - 3 } \cline { 5 - 6 } \cline { 5 - 6 } & $<1$ month & $1-42$ months & & $<$ month & $1-42$ months \\
\hline Unstable angina & 0 & 1 & 1 & 4 \\
Reinfarction & 0 & 1 & & 1 & 3 \\
Congestive heart failure & 0 & 0 & & 0 & 1 \\
PTCA/CABG & 0 & 2 & & 3 & 8 \\
Total & $0(0 \%)^{\star}$ & $4(9 \cdot 8 \%) \dagger$ & & $5(9 \cdot 6 \%)^{\star}$ & $16(30 \cdot 8 \%) \dagger$
\end{tabular}

CABC, coronary artery bypass graft surgery; PTCA, percutaneous transluminal coronary angioplasty.

Intergroup: $P$ * $\leqslant 0.01, \dagger \leqslant 0.02$.

Table 4 Causes of deaths according to the type of non- $Q$ wave myocardial infarction during the first month and 41 subsequent months after myocardial infarction. Data are expressed as number of patients or as incidence (\%) to related variable

\begin{tabular}{llllll}
\hline & \multicolumn{2}{l}{$\begin{array}{l}T \text { wave inversion } \\
(n=41)\end{array}$} & & \multicolumn{2}{l}{$\begin{array}{l}S T \text { segment depression } \\
(n=52)\end{array}$} \\
\cline { 2 - 3 } \cline { 5 - 6 } \cline { 5 - 6 } & $<1$ month & $1-42$ months & $<1$ month & $1-42$ months \\
\hline Reinfarction & 1 & 0 & 2 & 2 \\
Congestive heart failure & 0 & 1 & 0 & 0 \\
Sudden death & 1 & 1 & 0 & 2 \\
Post-PTCA/CABG* & 0 & 0 & & 1 & 1 \\
Unidentified & 0 & 1 & & 0 & 0 \\
Total & $2(4.9 \%)$ & $3(7 \cdot 3 \%)$ & & $3(5 \cdot 8 \%)$ & $5(9.6 \%)$ \\
\hline
\end{tabular}

PTCA, percutaneous transluminal coronary angioplasty; CABC, coronary artery bypass graft surgery.

$\star$ During the first week of treatment.

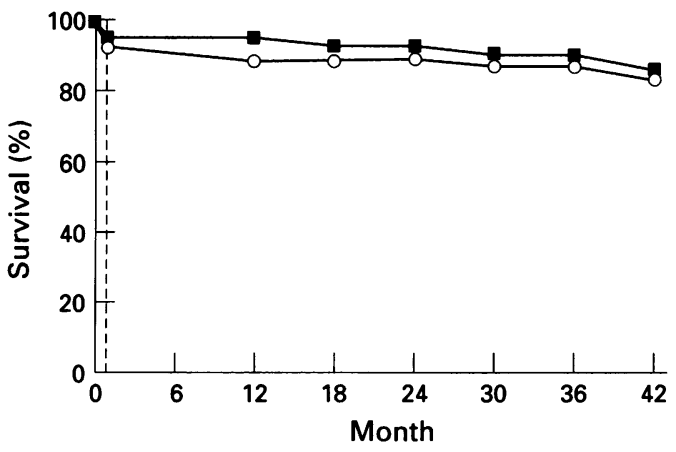

Figure 2 Cumulative survival (\%) at selected times in patients with $T$ wave inversion (G) and $S T$ segment depression $(O)$ non- $Q$ wave myocardial infarction. Broken line indicates the one month follow up.

\section{Discussion}

Q WAVE AND NON-Q WAVE MYOCARDIAL INFARCTION

The terms "transmural" and "non-transmural" myocardial infarction, as detected by an ECG, imply a pathological counterpart, but correlation with the anatomical definition of transmural/non-transmural myocardial infarction at necropsy is poor. Consequently, the more appropriate ECG terms of $Q$ wave and non- $Q$ wave myocardial infarction have become widely accepted in medical writing and practice. ${ }^{14}$ Non-Q wave myocardial infarction is not associated with a specific ECG pattern, and patients may present with ST segment depression or T wave abnormalities or both without the evolution of $Q$ waves. However, confirmation of myocardial necrosis through raised plasma CKMB activity is required.

Prolonged chest pain and ST segment elevation on the admission ECG are now used as the principal criteria for prescribing thrombolytic treatment in patients with evolving acute myocardial infarction, ${ }^{15}$ the justification being that acute ST segment elevation represents transmural ischaemia resulting from total occlusion of a coronary artery and is a precursor of transmural ( $Q$ wave) myocardial infarction. ${ }^{16}$ Therefore, the importance of early hospital admission for thrombolytic treatment (the success of which is critically time dependent) make it both relevant and feasible to examine the significance of acute ST-T segment shifts during the early course of an evolving myocardial infarct. ${ }^{17-19}$

\section{CARDIAC ISOENZYME ANALYSIS}

Our data accord with other studies ${ }^{52021}$ which have shown that non-Q wave myocardial infarction is associated with low CKMB release and a reduced incidence of congestive heart failure postinfarction-probably because of the small extent of myocardial necrosis.

PROGNOSIS AFTER A NON-Q WAVE MYOCARDIAL INFARCTION

The prognosis of patients who develop non- $Q$ wave acute myocardial infarction is uncertain. Only a few studies have reported a favourable outlook in patients with a first non-Q wave infarct. Mahony and associates ${ }^{22}$ reported an excellent in-hospital and one year survival rate 
in 24 patients; however, data about recurrent ischaemic events were not reported. Similarly, Coll and associates ${ }^{23}$ reported good long term survival in 28 patients after a first non- $Q$ wave infarct, though subsequent coronary events were not clearly identified. Krone and associate $^{20}$ reported a favourable outcome in 41 patients less than 60 years of age who presented with non- $Q$ wave infarction. In that study, the causes of death were not reported.

In examining the prognosis of discharged patients, the majority of published studies have either found the long term survival rates to be similar $^{2124-26}$ or worse ${ }^{2728}$ for patients with non-Q wave infarction compared with patients with $Q$ wave infarction.

\section{ST-T SHIFT IN NON-Q WAVE MYOCARDIAL INFARCTION}

Our study extends the findings of these previous reports in defining better the clinical implications and prognosis of patients after a non-Q wave infarction. We considered the ST-T shift to be a possible prognostic factor for stratification. There have been few studies of the significance of ECG findings in non-Q wave myocardial infarction, ${ }^{12} 29$ and this is important because most myocardial infarctions (within the first several hours) begin without $Q$ waves. Hence, we emphasise the distinction of these types of non- $Q$ wave infarction since different types of treatment may be chosen in the initial hours after the onset of an acute myocardial infarct.

\section{ANGIOGRAPHIC CRITERIA FOR PROGNOSTIC EVALUATION}

Previous postinfarction angiographic studies have shown that patency of the infarct related coronary artery is a frequent finding among patients with non- $Q$ wave myocardial infarction, ${ }^{93031}$ possibly related to spontaneous early reperfusion. ${ }^{14}$ In the present study, this angiographic picture was much more frequent in patients with ST segment depression $(76.9 \%)$ than those with $\mathrm{T}$ wave inversion $(14.6 \%)$. It is known that patients with patent infarct vessels are subjected to a higher incidence of subsequent ischaemic cardiac events than those with total occlusion of the infarct related artery since greater residual myocardium is at risk. ${ }^{89}$ Consequently, a poor outcome is more likely in the former set of patients.

With respect to left ventricular dysfunction, we found that both the patients with $T$ wave inversion and the patients with ST segment depression had similar and normal left ventricular ejection fractions. This is a usual finding among patients with non- $Q$ wave myocardial infarction. ${ }^{37}$

\section{CLINICAL IMPLICATIONS}

It is clear that other clinical variables and standard risk factors have an important predictive value in risk stratification after myocardial infarction. Several other studies have identified subgroups of patients with non- $Q$ wave myocardial infarction with increased case fatality rates. Scheinman and Abbott ${ }^{8}$ reported higher mortality rates for patients with non-Q wave infarction accompanied by raised cardiac enzyme peaks than for patients with $Q$ wave infarction and low enzyme release. Rigo and associates $^{9}$ found a significantly higher incidence of abnormal QRS complexes in patients with non- $Q$ wave infarction than in patients with $Q$ wave infarction. Furthermore, other studies ${ }^{24} 3233$ have reported low survival rates for patients with non-Q wave infarction complicated by an infarct extension during their hospital admission.

We believe that one of the mechanisms accounting for the poor outcome of patients with ST segment depression is that these patients suffered "incomplete infarctions", that is, they had potentially jeopardised myocardium within the perfusion zone of the patent infarct related vessel. Therefore, they were exposed to repetitive ischaemic events. We observed that patients with ST segment depression had a fivefold higher incidence of cardiac events during the total follow up period compared with patients with $T$ wave inversion. However, it must be pointed out that the need for coronary angioplasty or bypass surgery could have been influenced by subjective criteria as well as by the angiographic findings. Another possible mechanism is the existence of impaired or threatened collateral circulation ${ }^{34}$; unfortunately, the functional significance of collateral vessels in our patients was unclear.

Finally, our interpretation of the data obtained in this study is that the ST-T shift present in the diagnostic ECG is capable of outlining two subgroups of patients with non- $Q$ wave myocardial infarction with distinct outcomes and angiographic characteristics: patients with $\mathrm{T}$ wave inversion, who have a favourable outcome, and patients with ST segment depression, who have a poor prognosis, possibly because of a higher incidence of residual stenosis of the infarct related artery. However, persistent ST depression was not an independent risk factor for mortality. Therefore, ST segment depression is a potential predictor of adverse short and long term cardiac events for patients with non- $Q$ wave myocardial infarction. These data may provide a guide to therapeutic decision making. Nevertheless, the role of thrombolytic treatment in patients with evolving myocardial infarction characterised chiefly by ST segment depression remains to be elucidated.

1 Burke GL, Edlavitch SA, Crow RS. The effects of diagnostic criteria on coronary heart disease. $f$ Clin Epidemio 1990;3:93-9.

2 Goldberg RJ, Gore JM, Alpert JS, Dalen JE. Recent changes in attack and survival rates of acute myocardial infarction (1975 through 1981) - the Worcester Heart Attack Study IAMA 1986;225:2774-9.

3 Goldberg RJ, Gore JM, Alpert JS, Dalen JE. Non-Q wave myocardial infarction: recent changes in occurrence and prognosis - a community-wide perspective. Am Heart $\mathcal{F}$ 987;113:273-9.

4 Edlavitch SA, Crow R, Burke GL, Baxter J. Secular trends in $Q$ wave and non-Q wave acute myocardial infarction Circulation 1991;83:492-503.

5 Cheilton MD. Non-Q wave infarction-diagnosis, prognosis, and treatment. Adv Intern Med 1988;33:267-94.

6 Gheorghiade M, Schultz L, Tilley B, Kao W, Goldstein S. Natural history of the first non- $Q$ wave myocardial infarction in the placebo arm of the Beta-Blocker Heart Attack Trial. Am Heart f 1991;122:1548-53.

7 Borzak S, Rosman HS. Non-Q wave myocardial infarction Henry Ford Hosp Med $\mathfrak{f}$ 1992;39:256-62. 
8 Scheinman MM, Abbott JA. Clinical significance of transmural versus nontransmural electrocardiographic changes in patients with

1973;55:602-7.
Rigo P, Murray M, Taylor DR, Weisfeldt ML, Strauss HW, Pitt $\mathrm{B}$. Hemodynamic and prognostic findings in patients with transmural and nontransmural infarction. Circulation 1975;51:1064-70.

10 Cannom DS, Levy W, Cohen LS. The short- and long-term prognosis of patients with transmural and nontransmural myocardial infarction. $A m f M e d$ 1976;61:452-8.

11 Boden WE, Kleiger RE, Mehta P, et al. ST-segment depression on the admission ECG is a determinant of adverse long-term outcome in non-Q wave myocardial infarction-a prospective analysis from the Diltiazem Reinfarction Study [abstr]. $₹ \mathrm{Am}$ Coll Cardiol 1988;11: Reinfar.

12 Gibson RS, Beller GA, Gheorghiade $M$. The prevalence and clinical significance of residual myocardial ischemia two weeks after uncomplicated non-Q wave infarctionprospective

13 Ferlinz J, Gorlin R, Cohn PF, Herman MV. Left ventricular performance in patients with coronary artery disease.

14 Boden WE, Gibson RS, Schechtman KB, et al. ST segmen shifts are poor predictors of subsequent $Q$ wave evolution in acute myocardial infarction-a natural history study of early non-Q wave infarction. Circulation 1989;79:537-48.

15 The TIMI Study Group. The thrombolysis in myocardia nfarction (TIMI) trial-phase I findings. $N$ Eng $f$ Med 1985;312:932-6.

16 Laffel GL, Braunwald E. Thrombolytic therapy-a new strategy for the treatment of acute myocardial infarction (part 1). N Eng ₹ Med 1983;311:710-17.

17 Madias JE. The earliest ECG sign of acute myocardial infarction. $f$ Electrocardiol 1977;10:193-200.

18 McGuiness JB, Begg TB, Semple TB. First ECG in recent myocardial infarction, $B M 7$ 1976;ii:449-56.

19 Short D. The earliest ECG evidence of myocardial infarction. Br Heart f 1970;32:6-21.

20 Krone FJ, Friedman E, Thanavaro S, Miller JP, Kleiger RE, Oliver GC. Long-term prognosis after first $Q$ wave (transmural) or non- $Q$ wave (nontransmural) myocardial infarction analysis of 593 patients. Am $\mathcal{F}$ Cardiol 1983;52: t234-9.

21 Lekakis J, Katsoyanni K, Trichopoulos D, Tsitouris G. Q versus non- $Q$ wave myocardial infarction: clinical characteristics and six-month prognosis. Clin Cardiol 1984;7: 283-90.

22 Mahony C, Hindman MC, Aronin N, Wagner GS Prognostic differences in subgroups of patients with elec- trocardiographic evidence of subendocardial or transmural myocardial infarction - the favorable outlook for patients with an initially normal QRS complex. Am $\mathcal{F}$ Med 1980;69: 183-6.

23 Coll S, Castaner A, Sanz G. Prevalence and prognosis after a first transmural myocardial infarction. Am F Cardiol 1983; $51: 1584-8$

24 Nicod P, Gilpin E, Dittrich H, et al. Short- and long-term clinical outcome after $Q$ wave and non- $Q$ wave myocardial infarction in a large patient population. Circulation 1989; 79:528-36.

25 Maisel AS, Ahnve S, Gilpin E, et al. Prognosis after extension of myocardial infarct: the role of $Q$ wave and non- $Q$ wave myocardial infarction. Circulation 1985;71:211-20.

26 Connolly DC, Elveback LR. Coronary heart disease in residents of Rochester, Minnesota. VI. Hospital and posthospital course of patients with transmural and subendohospital course of patients with transmural and subendocardial $375-80$.

27 Cohen M, Hawkins L, Greenberg S, Fuster V. Usefulness of ST-segment changes in greater than or equal to two leads on the emergency room electrocardiogram in either unstable angina pectoris or non- $Q$ wave myocardial infarction in predicting outcome. Am $\mathcal{F}$ Cardiol 1991;67:1368-73.

28 Schechtman KB, Kleiger RE, Boden WE, et al. The relationship between one-year mortality and infarct location in patients with non-Q wave myocardial infarction. Am Heart f 1992;123:1175-81.

29 Huey BL, Gheorghiade $M$, Crampton RS, et al. Acute non- $Q$ wave myocardial infarction associated with early ST-segment elevation-evidence for spontaneous reperfusion and implications for thrombolyric trials. $\mathcal{F} \mathrm{Am}$ Coll Cardiol 1987;9:18-25.

30 Nicholson MR, Roubin GS, Bernstein L, Harris PJ, Kelly DT. Prognosis after an initial non- $Q$ wave myocardial infarction related to coronary artery anatomy. $A m \mathcal{F}$ Cardiol 1983;52:462-71.

31 DeWood MA, Stifter WF, Simpson CS, et al. Coronary arteriographic findings soon after non-Q wave myocardial infarction. $N$ Engl F Med 1986;315:417-23.

32 Boden WE, Schechtman KB, Capone RJ, Schwartz DJ, Roberts $R$. Importance of early recurrent ischemia on oneyear survival after non- $Q$ wave acute myocardial infarcyear survival after non-Q wave acute
tion. $A m \Im$ Cardiol 1989;64:799-801.

33 Schechtman KB, Capone RJ, Kleiger RE, et al. Risk stratification of patients with non- $Q$ wave myocardial infarccation of patients with non- $Q$ wave myocardial infarc-
tion-the critical role of ST segment depression. tion-the critical role of

34 MacDonald RG, Hill JA, Feldman RL. ST-segment response to acute coronary occlusion: coronary hemodynamic and angiographic determinants of direction of ST-segment shift. Circulation 1986;74:973-9. 